\title{
Pengembangan Board Game TITUNGAN untuk Melatih Kemampuan Berpikir Kreatif Matematis Siswa
}

\author{
Joko Widiyanto ${ }^{*}$, Tri Nova Hasti Yunianta ${ }^{2}$ \\ Pendidikan Matematika, Universitas Kristen Satya Wacana \\ Jalan Diponegoro No. 52-60, Salatiga, Jawa Tengah, Indonesia \\ 1*202017066@student.uksw.edu; ${ }^{2}$ trinova.yunianta@uksw.edu
}

Artikel diterima: 09-02-2021, direvisi: 26-09-2021, diterbitkan: 30-09-2021

\begin{abstract}
Abstrak
Berpikir kreatif adalah salah satu komponen penting dalam mengembangkan berpikir unggul untuk menciptakan manusia unggul. Melatih kemampuan berpikir kreatif dapat menggunakan board game. Penelitian ini dilakukan untuk mengembangkan suatu produk berupa board game TITUNGAN yang valid, praktis dan efektif digunakan untuk melatih kemampuan berpikir kreatif matematis siswa. Penelitian pengembangan ini menggunakan contoh pengembangan ADDIE sebagai metode penelitian. Subjek dalam penelitian ini sebanyak 8 siswa SMP Negeri 3 Tanjung Bintang. Instrumen penelitian yang digunakan berupa angket daftar isian (checklist) dan tes untuk menguji kevalidan, kepraktisan dan keefektifan. Hasil dari persentase rata-rata kevalidan sebesar 92,67\% (lebih dari 90\%) yang termasuk dalam kategori sangat Valid dan persentase rata-rata kepraktisan sebesar $80,9 \%$ (lebih dari $80 \%$ ) yang termasuk dalam kategori Praktis, sedangkan hasil uji paired $t$ test menghasilkan perbedaan yang signifikan antara nilai pretest dan posttest. Dapat disimpulkan bahwa board game TITUNGAN dapat dikatakan valid, praktis dan efektif digunakan untuk melatih kemampuan berpikir kreatif matematis siswa.

Kata Kunci: Berpikir Kreatif, Board game TITUNGAN, Matematika, Pengembangan.
\end{abstract}

\section{Development of TITUNGAN Board Game to Train Students' Mathematical Creative Thinking Ability}

\begin{abstract}
Creative thinking is one of the important in developing superior thinking to create superior humans. Creative thinking skills can be trained using board games. This study aims to develop a TITUNGAN board game that is valid, practical, and effective in trained students' mathematical creative thinking ability. This development research uses the example of ADDIE development as a research method. The subjek in this study were 8 students of SMP Negeri 3 Tanjung Bintang. The research instruments were a checklist questionnaire and a test to test the validity, practicality, and effectiveness. The result of validity obtained an average percentage of $92,67 \%$ (more than 90\%) which is included in the very valid category and an average percentage of the practicality of $80,9 \%$ (more than $80 \%$ ) which is included in the practical category, while the result of paired t-test that there is a significant difference between the pretest and posttest scores. It can be concluded that the TITUNGAN board game can be valid, practical, and effective to train students' mathematical creative thinking ability.

Keywords: Creative Thinking, TITUNGAN board game, Mathematics, Development.
\end{abstract}




\section{Pendahuluan}

Berpikir kreatif merupakan salah satu komponen atau aspek penting dalam mengembangkan berpikir unggul untuk menciptakan manusia unggul (Sudarma, 2013:231-232; Nurhikmayati \& Sunendar, 2020). Hasil kemampuan berpikir kreatif dari manusia-manusia unggul dapat melahirkan karya-karya yang spektakuler dan bermanfaat bagi kehidupan manusia luas (Syahara \& Astutik, 2021). Salah satu contohnya yaitu Bill Gates yang merupakan pendiri dari Microsoft dan Nadiem Makarim yang merupakan pendiri aplikasi Go-Jek.

Permendikbud no 20 tahun 2016 tentang Standar Kompetensi Lulusan (SKL) pendidikan dasar dan menengah menyatakan bahwa setiap lulusan satuan Pendidikan dasar dan menengah dituntut untuk memiliki keterampilan berpikir dan bertindak kreatif sebagai perkembangan dari pembelajaran di sekolah. Kemampuan berpikir kreatif tersebut harus dimiliki peserta didik, agar mereka dapat mengelola dan memanfaatkan teknologi dan informasi di masa yang akan datang karena ilmu pengetahuan dan teknologi sudah sangat berkembang pesat (Saefudin, 2012: 38; Widadi, 2016: 153). Kemampuan berpikir kreatif sangat penting juga bagi setiap lulusan agar mereka terbekali dengan kemampuan yang dapat bersaing di masa sekarang ini (Amrullah, 2017: 378).

Sudarma (2013) menyatakan bahwa melatih dan mengembangkan kemampuan berpikir kreatif dapat menggunakan model berpikir secara divergen atau mengembang dengan orientasi pada suatu jawaban yang baik atau benar. Terdapat empat indikator kemampuan berpikir kreatif, yaitu: (1) kefasihan; (2) fleksibilitas; (3) otentisitas berpikir; dan (4) elaborasi (Munandar, 1995). Kita dapat melatih kemampuan berpikir kreatif seseorang dengan melihat banyak jawaban yang berbeda dari suatu masalah.

Matematika merupakan salah satu disiplin ilmu dimana kemampuan berpikir kreatif dapat dipraktekkan melalui berbagai jawaban pada soal (Purnamasari \& Afriansyah, 2021; Muhtadi, Rochmad, \& Isnarto, 2021). Proses kreatif dalam matematika tidak selalu menemukan rumus, tetapi apabila individu dapat memvisualkan soal-soal matematika dan memberikan banyak jawaban yang berbeda dengan caranya sendiri sudah dapat menggunakan kemampuan berpikir kreatif dalam pembelajaran matematika (Zahar, 2009: 19). Terdapat banyak materi dalam matematika yang dapat melatih kemampuan berpikir kreatif dengan memberikan banyak jawaban yang berbeda (Nugraha \& Basuki, 2021), salah satunya materi operasi hitung bilangan.

Ketika siswa sudah dapat menggunakan kemampuan berpikir kreatif pada beberapa ide dalam matematika, maka siswa dapat menjadi lebih baik dalam memperoleh pemahaman (Faturohman \& Afriansyah, 2020: 108). Pada kenyataannya prosesproses berpikir kreatif pada pembelajaran matematika jarang dilatih karena cenderung difokuskan pada bentuk penilaian yang ditujukan pada jawaban yang benar (Sumartini, 2019: 15). Hal ini mengakibatkan siswa cenderung untuk mencari jawaban yang benar dan tunggal. Sejalan dengan pendapat sebelumnya, Widadi (2017: 153) mengemukakan bahwa kemampuan berpikir kreatif kurang dilatih 
dalam pembelajaran matematika, karena selama ini lebih menekankan dalam hafalan dan mencari satu jawaban yang benar pada soal-soal matematika yang diberikan. Oleh karena itu, diperlukan strategi yang tepat untuk melatih kemampuan berpikir kreatif siswa pada pembelajaran matematika.

Salah satu strategi yang dapat digunakan untuk melatih kemampuan berpikir kreatif dalam pembelajaran matematika adalah dengan menggunakan education game. Sebab education game dapat meningkatkan kemampuan berpikir kreatif, serta meningkatkan hasil belajar dan pengetahuan bagi siswa (Afriansyah, 2013; Sanusi dkk, 2020: 513). Holis (2017), menyatakan bahwa kemampuan berpikir kreatif anak semakin meningkat setelah anak mendapatkan pelajaran dengan game. Sejalan dengan pendapat sebelumnya, Kusuma dkk (2019) menyatakan bahwa game yang baik adalah game yang dapat melatih dan meningkatkan kelincahan pemain, serta keaktifannya. Game dipilih karena memiliki karakteristik yang menyenangkan, menantang, dan membuat ketagihan yang dapat memberikan nilai edukasi dalam permainan, serta dapat digunakan sebagai media pelatihan dan pembelajaran (Nikensasi dkk, 2012; Supra, 2016).

Game banyak jenisnya, salah satu yang dapat digunakan yaitu board game. board game adalah permainan yang dapat melatih pemain untuk memprediksi hasil sementara untuk bergerak, serta dapat mendeteksi pola yang ada dalam dari media sebagai model atau alat peraga dalam pembelajaran (Tristanti, Akbar \& Rahayu, 2021; Nusantara \& Irawan, 2012:
23). Board game sering disebut permainan papan, karena media yang digunakan berupa papan permainan, tidak hanya bermain dan bersaing saja tetapi juga dapat melatih keaktifan dalam komunikasi dengan lawan bermain (Mardiani, 2018; Prambudi \& Yunianta, 2020: 10).

Terdapat beberapa penelitian yang telah menerapkan media board game dan kemampuan berpikir kreatif, diantaranya yaitu penelitian yang dilakukan oleh Kusumaningtyas \& Yunianta (2019) tentang pengembangan media scrabble dengan materi bilangan bulat yang terbukti valid, pratis dan efektif digunakan dalam meningkatkan procedural fluency matematika siswa. Selain itu juga terdapat penelitian yang serupa, yaitu penelitian yang dilakukan oleh Andini \& Yunianta (2018) dengan mengembangkan The Adventure of Algebra yang terbukti valid, praktis dan efektif digunakan sebagai sarana Latihan materi aljabar yang menantang bagi siswa kelas VII SMP. Sejalan dengan penelitian sebelumnya, Mawanto dkk (2020) telah mengembangkan media cerita bergambar yang terbukti valid, praktis dan efektif digunakan untuk melatih kemampuan berpikir kreatif siswa pada materi pecahan kelas II.

Berdasarkan latar belakang masalah dan penelitian relevan yang ada. Peneliti ingin mengembangan game edukasi berupa board game yang bernama "TITUNGAN" dengan materi operasi hitung pada bilangan bulat. Dalam board game ini, kita dapat belajar bagaimana suatu bilangan dapat diselesaikan menggunakan angka 1 sampai 9 dan operasi hitung. Tidak hanya 
itu juga, dalam board game ini diperlukan strategi agar pemain dapat Menyusun tiga keping warna secara horizontal, vertical atau diagonal dengan susunan kata W-OW.

Penelitian ini dilakukan untuk memperoleh suatu game edukasi yang valid, praktis dan efektif digunakan untuk melatih kemampuan berpikir kreatif matematis siswa. Dengan adanya board game TITUNGAN diharapkan dapat melatih kemampuan berpikir kreatif dengan melalui penemuan solusi-solusi berbeda dari biasanya dalam materi operasi hitung.

\section{Metode}

Penelitian pengembangan ini menggunakan contoh pengembangan ADDIE, yang meliputi 5 tahapan yaitu Analyze, Design, Development, Implementation, dan Evaluation sebagai metode penelitiannya. Produk yang dihasilkan pada penelitian pengembangan ini yaitu board game yang dapat digunakan untuk melatih kemampuan berpikir kreatif matematis siswa dalam materi operasi hitung. Board game tersebut akan diujicobakan kepada 8 siswa SMP Negeri 3 Tanjung Bintang.

Tes, non-tes dan dokumentasi digunakan sebagai Teknik pengumpulan data dengan instrumen penelitian yang digunakan berupa angket daftar isian (checklist) dan tes untuk menguji kevalidan, kepraktisan dan keefektifan. Analisis untuk menguji kevalidan dan kepraktisan menggunakan rumus: $\boldsymbol{P}(\boldsymbol{s})=\frac{\boldsymbol{s}}{\boldsymbol{N}} \times \mathbf{1 0 0} \%$ dengan keterangan $S$ : jumlah skor perolehan dan $N$ : jumlah skor maksimum (Wandani \& Nasution, 2017: 91; Oktaviana
\& Trimulyono, 2018: 189; Aswardi dkk, 2019: 54). Hasil persentase akan menjadi kategori penilaian dari produk yang dikembangkan dengan kriteria pada Tabel 1 dan Tabel 2 (Aswardi dkk, 2019: 54).

Tabel 1.

Kriteria Kevalidan Produk

\begin{tabular}{|cc|}
\hline Tingkat Pencapaian (\%) & Kategori \\
\hline $90-100$ & Sangat Valid \\
\hline $80-89$ & Valid \\
\hline $65-79$ & Cukup Valid \\
\hline $55-64$ & Kurang Valid \\
\hline $0-54$ & Tidak Valid \\
& Tabel 2.
\end{tabular}

Kriteria Kepraktisan Produk

\begin{tabular}{|cc|}
\hline \multicolumn{1}{c}{ Tingkat Pencapaian (\%) } & Kategori \\
\hline $90-100$ & Sangat Praktis \\
\hline $80-89$ & Praktis \\
\hline $65-79$ & Cukup Praktis \\
\hline $55-64$ & Kurang Praktis \\
\hline $0-54$ & Tidak Praktis \\
\hline
\end{tabular}

Uji paired t-test digunakan untuk menguji keefektifan pada pretest dan posttest yang akan dianalisis menggunakan SPSS, sedangkan pada lembar respons siswa menggunakan rumus:

$\boldsymbol{X}=\frac{\text { skor total respons siswa }}{\text { skor maksimum respons siswa }} \times \mathbf{1 0 0} \%$ dengan Persentase hasil penilaian dikategorikan menurut kriteria yang terdapat pada Tabel 3 (Hidayatullah, 2016: 85).

Tabel 3.

Kriteria Penilaian Respons Siswa

\begin{tabular}{|cc|}
\hline Tingkat Pencapaian (\%) & Kategori \\
\hline $\mathbf{8 2}-\mathbf{1 0 0}$ & Sangat Baik \\
\hline $\mathbf{6 3 - \mathbf { 8 1 }}$ & Baik \\
\hline $\mathbf{4 4 - 6 2}$ & Tidak Baik \\
\hline $\mathbf{2 0}-\mathbf{4 3}$ & Sangat Tidak Baik \\
\hline
\end{tabular}

\section{Hasil dan Pembahasan}

\section{A. Hasil Penelitian}

Berikut ini uraian dari tahapan pada model ADDIE dalam pengembangan board game TITUNGAN, yaitu: 
1) Tahap Analysis (Analisis)

Pengembangan board game TITUNGAN diawali dengan melakukan analisis kebutuhan, analisis karakter siswa dan analisis kurikulum. Hasil dari tahap analisis berupa adanya kebutuhan media dalam bentuk permainan yang dapat menumbuhkan antusias siswa dalam belajar. Hal ini dikarenakan Sebagian besar siswa SMP masih memiliki jiwa bermain dan daya kompetitif yang tinggi. Permainan yang dibutuhkan juga disesuaikan dengan tuntutan kurikulum yang berlaku yaitu kurikulum 2013. Pada kurikulum 2013 terdapat beberapa aspek yang harus dimiliki lulusan, salah satunya harus memiliki keterampilan berpikir dan bertindak kreatif.

\section{2) Tahap Design (Desain)}

Tahap berikutnya adalah tahap desain. Pada tahap ini dimulai dengan Menyusun rancangan board game awal dan bagianbagian kecil yang ada dalam penggunaan board game, serta Menyusun buku panduan permainan dengan menggunakan Corel Draw. Kemudian peneliti juga Menyusun lembar kevalidan, kepraktisan dan keefektifan yang berupa angket daftar isian (checklist) dan tes. Berikut rancangan desain board game awal dan bagian-bagian kecil yang ada dalam penggunaan board game, serta buku panduan permainan.

a) Desain Papan Permainan; Desain papan permainan ini dibuat menggunakan aplikasi Corel Draw yang berisikan 64 persegi kecil dengan bulatan warna dan bilangan ditengahnya. Bilangan-bilangan tersebut akan ditentukan hasil operasi bilangannya oleh pemain.
Berikut desain papan permainan yang dapat dilihat pada Gambar 1, Gambar 2 dan Gambar 3.

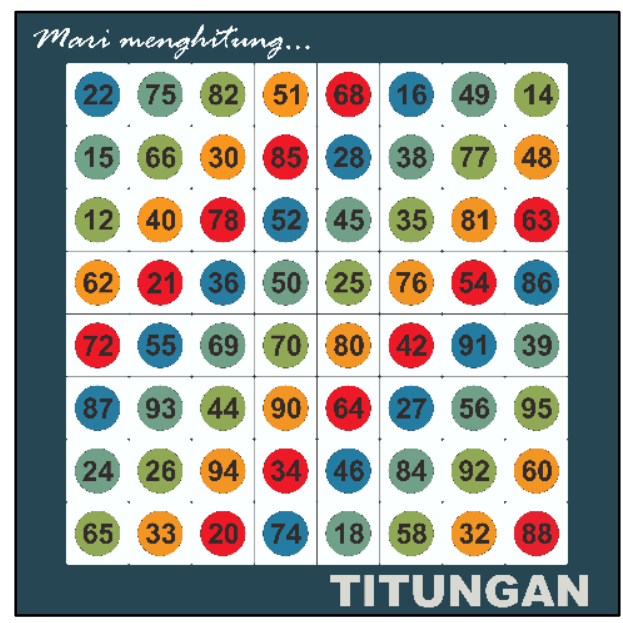

Gambar 1. Desain Bagian Depan Papan Permainan seril.

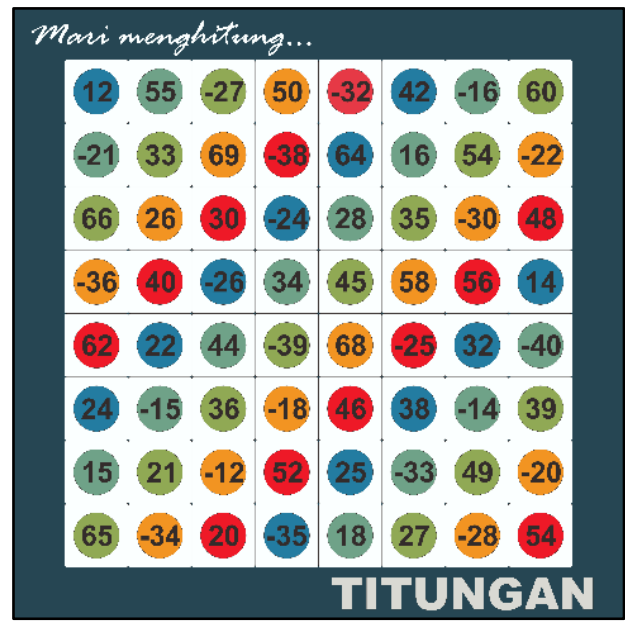

Gambar 2. Desain Bagian Depan Papan Permainan seri II.

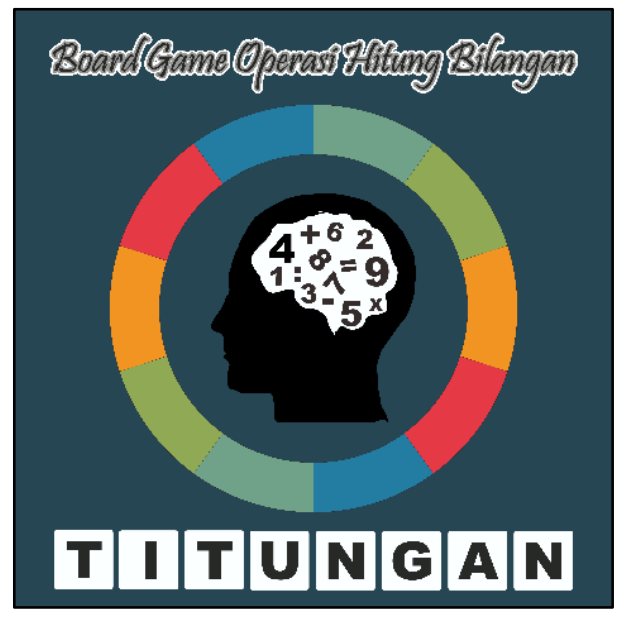

Gambar 3. Desain Bagian Belakang Papan Permainan. 
Dalam papan permainan seri I terdiri atas bilangan-bilangan komposit kurang dari 100 yang dapat ditentukan hasil operasinya melalui keping angka 1 sampai angka 9. Sedangkan pada papan permainan seri II terdiri atas bilangan-bilangan lebih dari -100 dan kurang dari 100 yang dapat ditentukan hasil operasinya melalui keping angka 1 sampai angka 9 dan keping angka -9 sampai angka -1.

b) Desain Keping Operasi Hitung; Desain keping operasi hitung ini dibuat menggunakan aplikasi Corel Draw yang terdiri dari operasi pembagian, perkalian, pengurangan, dan penjumlahan ditengahnya. Keping operasi hitung berbentuk persegi yang akan digunakan sebagai tanda operasi hitung oleh pemain. Berikut desain keping operasi hitung yang dapat dilihat pada Gambar 4.

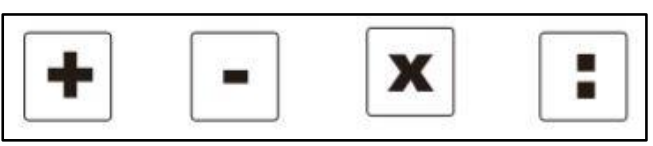

Gambar 4. Desain Keping Operasi Hitung.

c) Desain Keping Angka; Desain keping angka ini dibuat menggunakan aplikasi Corel Draw yang terdiri dari angka -9 sampai angka 9 kecuali 0 ditengahnya. Keping angka berbentuk persegi yang akan digunakan untuk menentukan hasil operasi bilangan pada papan permainan. Pada seri I keping angka yang digunakan yaitu keping angka 1 sampai angka 9, sedangkan pada seri II keping angka yang digunakan yaitu keeping angka 9 sampai angka 9 kecuali 0. Berikut desain keping angka yang dapat dilihat pada Gambar 5.

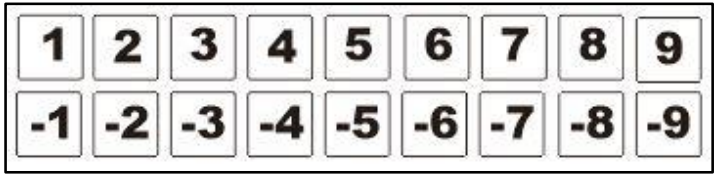

Gambar 5. Desain Keping Angka.

d) Desain Keping Warna; Desain keping warna ini dibuat menggunakan aplikasi Corel Draw yang terdiri atas 4 warna dengan masing-masing warna memiliki huruf $\mathrm{W}$ pada bagian depan dan huruf $O$ pada bagian belakang. Keping warna berbentuk persegi yang akan digunakan untuk menandai daerah dari hasil operasi bilangan yang sudah ditentukan oleh pemain. Berikut desain keping warna yang dapat dilihat pada Gambar 6 dan Gambar 7.

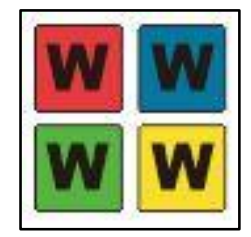

Gambar 6. Desain Keping Warna Bagian Depan.

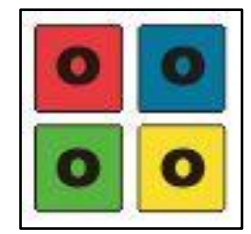

Gambar 7. Desain Keping Warna Bagian Belakang.

e) Desain Buku Panduan Permainan; Desain buku panduan permainan ini dibuat menggunakan aplikasi Corel Draw yang didalamnya terdapat pengertian board game TITUNGAN, komponen-komponen permainan, aturan permainan, dan cara bermain dalam board game TITUNGAN. Berikut desain buku panduan 
permainan yang dapat dilihat pada Gambar 8 dan Gambar 9.

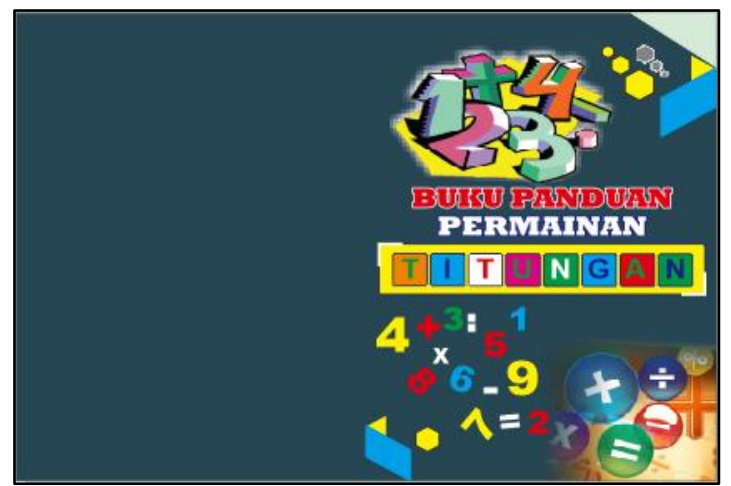

Gambar 8. Desain Cover Bagian Luar Buku Panduan Permainan.

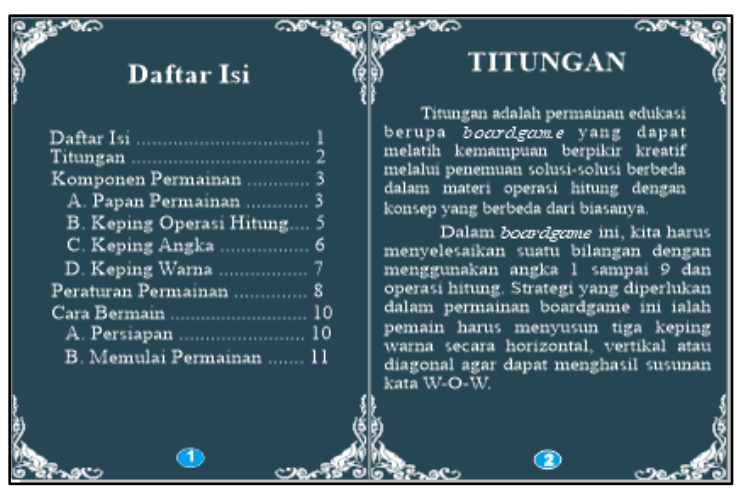

Gambar 9. Desain Isi Bagian Dalam Buku Panduan Permainan.

3) Tahap Development (Pengembangan)

Setelah semua rancangan board game selesai, proses selanjutnya yang dilakukan adalah memproduksi board game TITUNGAN. Pertama kali yang diproduksi yaitu papan permainan, keping operasi hitung, keping angka dan keping warna. Komponen-komponen permainan tersebut dicetak memakai papan bot dan stiker menggunakan bahan vinyl, setelah itu dilaminasi dengan menggunakan plastik supaya tidak mudah rusak. Papan permainan dicetak dengan ukuran $29 \mathrm{~cm} \times$ $29 \mathrm{~cm}$ yang didalamnya terdapat 64 persegi kecil berukuran $3 \mathrm{~cm} \times 3 \mathrm{~cm}$, sedangkan untuk masing-masing keping operasi hitung, keping angka dan keping warna dicetak dengan ukuran $3 \mathrm{~cm} \times 3 \mathrm{~cm}$. kedua, adalah box atau kemasan untuk board game yang dicetak menggunakan bahan kayu multipleks dengan ukuran $40 \mathrm{~cm} \times 30$ $\mathrm{cm} \times 5 \mathrm{~cm}$. Terakhir adalah buku panduan permainan yang dicetak dengan bahan kertas ivory 400 gram.

4) Tahap Implementation (Implemetasi)

Tahap yang keempat yaitu implementasi atau uji coba. Dalam tahap ini, board game TITUNGAN akan diujicobakan kepada 8 siswa SMP sebagai subjek penelitian yang diambil secara acak. Sebelum diujicobakan dilapangan, terlebih dahulu dilakukan uji kevalidan media dan materi dari board game TITUNGAN oleh validator yang ahli dibidangnya, serta uji kepraktisan media dari board game TITUNGAN oleh guru matematika. berikut hasil dari uji kevalidan dan kepraktisan yang sudah dilakukan:

a) Uji Kevalidan Media dan Materi; Uji kevalidan media dan materi dilakukan oleh 3 validator. Berikut ini hasil uji kevalidan media dan materi yang dapat dilihat pada Tabel 4 .

Tabel 4.

Hasil Uji Kevalidan Media dan Materi

\begin{tabular}{lcc|}
\hline \multicolumn{1}{|c}{ Aspek Penilaian } & $(\%)$ & Kategori \\
\hline $\begin{array}{l}\text { Tampilan } \\
\text { Boardgame }\end{array}$ & 93,33 & Sangat Valid \\
\hline Kebermanfaatan & 91,67 & Sangat Valid \\
\hline $\begin{array}{l}\text { Penggunaan dan } \\
\text { Pemeliharaan serta } \\
\text { Keekonomisan }\end{array}$ & 89,58 & Valid \\
\hline Pengemasan & 93,75 & Sangat Valid \\
\hline Kelayakan Isi & 95 & Sangat Valid \\
\hline \multicolumn{1}{|c}{ Rata-Rata } & 92,67 & Sangat Valid \\
\hline
\end{tabular}

Hasil rata-rata dari uji kevalidan media dan materi menunjukan persentase sebesar 92,67\% (lebih dari 90\%) yang termasuk dalam kategori sangat valid. Dari hasil 
presentase diatas dapat disimpulkan bahwa board game TITUNGAN valid dari segi media dan materi untuk digunakan.

b) Uji Kepraktisan Media; Uji kepraktisan media dilakukan oleh 2 guru matematika. Berikut ini hasil uji kepraktisan media yang dapat dilihat pada Tabel 5.

Tabel 5.

Hasil Uji Kepraktisan Media

\begin{tabular}{lcc|}
\hline \multicolumn{1}{c}{ Aspek Penilaian } & (\%) & Kategori \\
\hline $\begin{array}{l}\text { Persiapan } \\
\text { Penggunaan }\end{array}$ & 81,25 & Praktis \\
\hline Penggunaan & 77,08 & Cukup Praktis \\
\hline Pemilihan & 84,37 & Praktis \\
\hline Rata-Rata & 80,9 & Praktis \\
\hline
\end{tabular}

Hasil rata-rata dari uji kepraktisan media pada Tabel 5 menunjukan presentase sebesar 80,9\% (lebih dari $80 \%$ ) yang termasuk dalam kategori praktis. Dari hasil presentase tersebut dapat disimpulkan bahwa board game TITUNGAN praktis untuk digunakan.

Board game TITUNGAN diujicobakan kepada 8 siswa SMP Negeri 3 Tanjung Bintang yang diambil secara acak pada bulan januari 2021. Pada saat board game diujicobakan siswa sangat antusias dalam memainkan board game TITUNGAN. Siswa juga tidak sabar untuk menunggu giliran bermainnya karena siswa tersebut sudah menemukan hasil operasi dari bilangan yang diinginkan, sedangkan lawan bermainnya belum bisa menemukan hasil operasi dari bilangan yang diinginkan.

5) Tahap Evaluation (Evaluasi)

Tahap yang terakhir yaitu evaluasi. Tahap ini bertujuan untuk mengetahui keefektifan board game yang sudah dibuat dengan mengetahui perbedaan rerata dari pretest dan posttest. Berikut ini hasil uji paired t-test yang dapat dilihat pada Tabel 6.

Tabel 6.

Hasil Uji Paired t-test

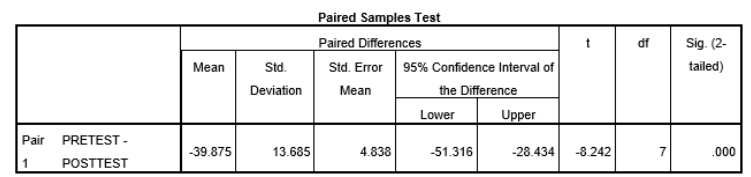

Uji paired t-test menghasilkan nilai Sig. (2-tailed) sebesar 0,000 (kurang dari 0,05), yang artinya terdapat perbedaan yang signifikan antara nilai pretest dan posttest. Hasil rerata pretest dikurangi rerata postest menghasilkan -39,875 (negatif), yang artinya nilai posttest secara signifikan lebih tinggi dibandingkan nilai pretest. Sehingga dapat disimpulkan bahwa terdapat perbedaan hasil belajar setelah dan sebelum menggunakan board game TITUNGAN dengan nilai posttest secara signifikan lebih tinggi dibandingkan dengan nilai pretest.

Dalam mengetahui keefektifan dari board game TITUNGAN dilihat juga dari hasil penilaian respons siswa. Berikut ini hasil penilaian respons siswa yang dapat dilihat pada Tabel 7.

Tabel 7.

Hasil Uji Paired t-test

\begin{tabular}{lcc|}
\hline \multicolumn{1}{c}{ Pernyataan } & (\%) & Kategori \\
\hline $\begin{array}{l}\text { Boardgame TITUNGAN } \\
\text { dapat menumbuhkan } \\
\text { minat belajar bagi siswa }\end{array}$ & 90,625 & $\begin{array}{c}\text { Sangat } \\
\text { Baik }\end{array}$ \\
\hline $\begin{array}{l}\text { Boardgame TITUNGAN } \\
\text { dapat melatih } \\
\text { kemampuan berpikir } \\
\text { kreatif siswa dalam } \\
\text { menghitung }\end{array}$ & 100 & $\begin{array}{c}\text { Sangat } \\
\text { Baik }\end{array}$ \\
\hline $\begin{array}{l}\text { Boardgame TITUNGAN } \\
\text { dapat memudahkan untuk } \\
\text { belajar matematika }\end{array}$ & 90,625 & $\begin{array}{c}\text { Sangat } \\
\text { Baik }\end{array}$ \\
\hline
\end{tabular}




\begin{tabular}{|lcc|}
\hline $\begin{array}{l}\text { Permainan pada } \\
\text { boardgame TITUNGAN } \\
\text { menantang }\end{array}$ & 90,625 & $\begin{array}{c}\text { Sangat } \\
\text { Baik }\end{array}$ \\
\hline $\begin{array}{l}\text { Tampilan pada boardgame } \\
\text { TITUNGAN menarik }\end{array}$ & 90,625 & $\begin{array}{c}\text { Sangat } \\
\text { Baik }\end{array}$ \\
\hline Rata-Rata & 92,5 & $\begin{array}{c}\text { Sangat } \\
\text { Baik }\end{array}$ \\
\hline
\end{tabular}

Hasil rata-rata dari penilaian respons siswa menunjukan persentase sebesar 92,5\% (lebih dari 82\%) yang termasuk dalam kategori sangat Baik. berdasarkan hasil pada uji paired t-test dan penilaian respons siswa dapat disimpulkan bahwa board game TITUNGAN dapat dikatakan efektif untuk digunakan.

\section{B. Pembahasan}

Berdasarkan hasil penelitian melalui metode pengembangan ADDIE di dapat sebuah produk berupa board game TITUNGAN yang valid, praktis, dan efektif digunakan untuk melatih kemampuan berpikir kreatif matematis siswa. hal ini sejalan dengan penelitian yang dilakukan oleh Mawanto dkk (2020) dengan mengembangkan media cerita bergambar yang terbukti valid, praktis, dan efektif digunakan untuk melatih kemampuan berpikir kreatif siswa dalam materi pecahan kelas II.

Kelebihan dari board game ini yaitu kita dapat belajar bagaimana suatu bilangan dapat diselesaikan menggunakan angka 1 sampai 9 dan operasi hitung. Tidak hanya itu juga, dalam board game ini diperlukan strategi agar pemain dapat Menyusun tiga keping warna secara horizontal, vertical atau diagonal dengan susunan kata W-OW.

Terdapat empat indikator kemampuan berpikir kreatif, yaitu: (1) kefasihan/ kelancaran; (2) fleksibilitas/ keluwesan; (3) otentisitas/keaslian berpikir; dan (4) elaborasi (Munandar, 1995). Berdasarkan penelitian yang sudah dilakukan, terlihat bahwa subjek telah memenuhi indikator kelancaran dan keluwesan. Hal ini dilihat Ketika subjek mengerjakan soal pretest dan posttest. Sebelum menggunakan board game TITUNGAN, subjek mengalami kesusahan dalam menentukan operasi hitung dan hanya dapat melakukan operasi hitung dengan dua angka saja. Sedangkan setelah menggunakan board game TITUNGAN, subjek sudah mulai lancar dalam menentukan operasi hitung dan mulai dapat menentukan operasi hitung dengan dua sampai empat angka.

Dalam bermain board game tersebut juga dapat melatih kemampuan interaksi sosial, karena Ketika bermain Board game tersebut harus berinteraksi dengan baik agar tidak terjadi perbedaan pendapat dengan lawan bermain. Hal ini sejalan dengan pendapat Prambudi \& Yunianta (2020: 10) yang menyatakan bahwa dalam bermain permainan papan atau board game bukan hanya bermain dan bersaing saja, tetapi juga melatih keaktifan komunikasi dengan lawan bermain.

\section{Penutup}

Berdasarkan hasil penelitian yang sudah dilakukan, diperoleh kesimpulan bahwa board game TITUNGAN dapat dikatakan valid, praktis, dan efektif digunakan untuk melatih kemampuan berpikir kreatif matematis siswa. Dilihat setelah siswa menggunakan board game TITUNGAN, Ketika siswa mengerjakan soal posttest, siswa sudah mulai lancar dalam menentukan operasi hitung dan mulai dapat menentukan operasi hitung dengan 
dua sampai empat angka. Dalam bermain board game tersebut juga dapat melatih kemampuan interaksi sosial, karena Ketika bermain Board game tersebut harus berinteraksi dengan baik agar tidak terjadi perbedaan pendapat dengan lawan bermain.

Pada penelitian selanjutnya disarankan untuk mengembangkan board game TITUNGAN ini dalam bentuk digital atau berbasis android untuk mengikuti perkembangan jaman agar siswa semakin semangat untuk belajar.

\section{Daftar Pustaka}

Afriansyah, E. A. (2013). Penjumlahan bilangan desimal melalui permainan roda desimal. In Prosiding Seminar Nasional Matematika dan Pendidikan Matematika, Jurusan Pendidikan Matematika FMIPA UNY(pp. 233240).

Amrullah, A. K. (2017). Implementasi Pembelajaran Berbasis Masalah untuk Melatihkan Kemampuan Berpikir Kreatif dan Penguasaan Konsep Siswa Kelas V Sekolah Dasar. Jurnal Review Pendidikan Dasar: Jurnal Kajian Pendidikan dan Hasil Penelitian, 3(1), 378-387.

Andini, M., \& Yunianta, T. N. H. (2018). The Development of Borad game "The Adventure of Algebra" in The Senior High School Mathematics Learning. Al-Jabar: Jurnal Pendidikan Matematika, 9(2), 95-109.

Aswardi, A., Mukhaiyar, R., Elfizon, E., \& Nellitawati, N. (2019) Pengembangan Trainer Programable Logic Gontroller Sebagai Media Pembelajaran Di SMK Negeri Kota Payakumbuh. JTEV
(Jurnal Teknik Elektro dan Vokasional), 5(1), 51-56.

Faturohman, I., \& Afriansyah, E. M. (2020). Peningkatan Kemampuan Berpikir Kreatif Matematis Siswa melalui Creative Problem Solving. Mosharafa: Jurnal Pendidikan Matematika, 9(1), 107-118.

Hidayatullah, M. S., \& Rakhmawati, L. (2016). Pengembangan Media Pembelajaran Berbasis Flip Book Maker Pada Mata Pelajaran Elektronika Dasar di SMK Negeri 1 Sampang. Jurnal Pendidikan Teknik Elektro, 5(1).

Holis, A. (2017). Belajar Melalui Bermain untuk Pengembangan Kreativitas dan Kognitif Anak Usia Dini.Jurnal Pendidikan UNIGA, 10(1), 23-37.

Kusuma, R. T., Mulyani, A., \& Rianto, H. (2019). Rancang Bangun Game "Legends of Spaceship" Menggunakan Game Maker Studio.Journal of Information System, Informatics and Computing, 3(2), 37-44.

Kusumaningtyas, I., \& Yunianta, T. N. H. (2019). Pengembangan Media Scrabble untuk Meningkatkan Procedural Fluency Matematika Siswa SMP. Jurnal Cendekia: Jurnal Pendidikan Matematika, 3(2), 300314.

Mardiani, D. (2018). Kemampuan Mahasiswa Memahami Persamaan Diferensial Bernauli melalui Model Pembelajaran Game Menempel Nama. Mosharafa: Jurnal Pendidikan Matematika, 7(1), 95-102.

Mawanto, A., Siswono, T. Y. E., \& Lukito, A. (2020). Pengembangan Media Cerita 
Bergambar untuk Melatih Kemampuan Berpikir Kreatif Siswa pada Materi Pecahan Kelas II. Jurnal Cendikia: Jurnal Pendidikan Matematika, 4(1), 424-437.

Muhtadi, D., Rochmad, R., \& Isnarto, I. (2021). Bahasa Matematis dalam Penentuan Waktu Siang-Malam menurut Tradisi Sunda. Plusminus: Jurnal Pendidikan Matematika, 1(2), 263-274.

Munandar, U. (1995). Pengembangan Kreativitas Anak Berbakat. Jakarta, Rineka Cipta.

Nikensasi, P., Kuswardayan, I., \& Sunaryono, D. (2012). Rancang Bangun Permainan Edukasi Matematika dan Fisika dengan Memanfaatkan Accelerometer dan Physics Engine Box2d pada Android. Jurnal Teknik ITS, 1(1), A255-A260.

Nugraha, M. R., \& Basuki, B. (2021). Kesulitan Kemampuan Pemecahan Masalah Matematis Siswa SMP di Desa Mulyasari pada Materi Statistika. Plusminus: Jurnal Pendidikan Matematika, 1(2), 235248.

Nurhikmayati, I., \& Sunendar, A. (2020). Pengembangan Project Based Learning Berbasis Kearifan Lokal Berorientasi pada Kemampuan Berpikir Kreatif dan Kemandirian Belajar. Mosharafa: Jurnal Pendidikan Matematika, 9(1), 1-12.

Nusantara, D. B., \& Irawan, A. H. (2012). Perancangan Boardgame Sebagai Media Pembelajaran IImu Pengetahuan Alam Untuk Anak SD
Kelas 1.Jurnal Sains dan Seni ITS, 1(1), F22-F27.

Oktaviana, A. N., \& Trimulyono, G. (2018). Kelayakan Teoritis Media Video Mind Mapping Untuk Melatih Kemampuan Berpikir Kreatif Peserta Didik Kelas $X$ Pada Materi Fungsi. BioEdu, 7(2), 187-193.

Prambudi, E. Y., \& Yunianta, T. N. H. (2020). Pengembangan Media Bus Race Algebra Pada Materi Bentuk Aljabar Untuk Siswa Kelas VII SMP. Jurnal Cendekia: Jurnal Pendidikan Matematika, 4(1), 8-22.

Purnamasari, A., \& Afriansyah, E. A. (2021). Kemampuan Komunikasi Matematis Siswa SMP pada Topik Penyajian Data di Pondok Pesantren. Plusminus: Jurnal Pendidikan Matematika, 1(2), 207-222.

Saefudin, A. A. (2012). Pengembangan kemampuan berpikir kreatif siswa dalam pembelajaran matematika dengan pendekatan pendidikan matematika realistik indonesia (PMRI). Al-Bidayah: Jurnal Pendidikan Dasar Islam, 4(1).

Sanusi, A. M., Septian, A., \& Inayah, S. (2020). Kemampuan Berpikir Kreatif Matematis dengan Menggunakan Education Game Berbantuan Android pada Barisan dan Deret. Mosharafa: Jurnal Pendidikan Matematika, 9(3), 511-520.

Sudarma, M. (2013). Mengembangkan Keterampilan Berpikir Kreatif. Jakarta, Rajawali Pers.

Sumartini, T. S. (2019). Kemampuan Berpikir Kreatif Mahasiswa Melalui Pembelajaran Mood, Understanding, 
Recall, Detect, Elaborate, and Review.

Mosharafa: Jurnal Pendidikan

Matematika, 8(1), 13-24.

Supra Ningrum, S. E. L. L. Y. (2016).

Pengembangan Media Visual Papan

Permainan pada Materi Bentuk

Aljabar Mata Pelajaran Matematika Kelas VII SMP Siti Aminah Surabaya. Jurnal Mahasiswa

Teknologi Pendidikan, 7(1).

Syahara, M. U., \& Astutik, E. P. (2021). Analisis Berpikir Kreatif Siswa dalam Menyelesaikan Masalah SPLDV ditinjau dari Kemampuan Matematika. Mosharafa: Jurnal Pendidikan Matematika, 10(2), 201212.

Tristanti, L. B., Akbar, S., \& Rahayu, W. A. (2021). Pengaruh Media Pembelajaran Game Edukasi Berbasis Construct terhadap Kemampuan Pemecahan Masalah dan Hasil Belajar Siswa. Mosharafa: Jurnal Pendidikan Matematika, 10(1), 129-140.

Wandani, N. M., \& Nasution, S. H. (2017). Pengembangan Multimedia Interaktif dengan Autoplay Media Studio pada Materi Kedudukan Relatif Dua Lingkaran. Jurnal Kajian Pembelajaran Matematika, 1(2), 9095.

Widadi, S. (2017). Pengembangan Perangkat Pembelajaran Dengan Pemecahan Masalah Untuk Melatih Kemampuan Berpikir Kreatif Siswa Kelas IV SD Materi Pecahan. Jurnal Review Pendidikan Dasar: Jurnal Kajian Pendidikan dan Hasil Penelitian, 2(2), 152-158.

Zahar, I. (2009). Belajar Matematikaku

Pembelajaran Matematika secara
Visual dan Kinestetik. Jakarta, PT Elex Media Komputindo.

\section{Riwayat Hidup Penulis Joko Widiyanto, S.Pd.}

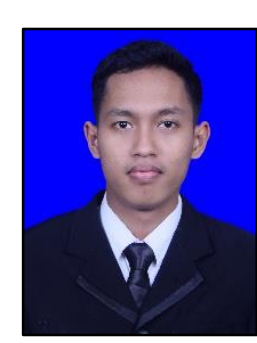

Lahir di Lampung Selatan, 24 Mei 1999. Studi S1 Pendidikan Matematika Universitas Kristen Satya Wacana.

Tri Nova Hasti Yunianta, M.Pd.

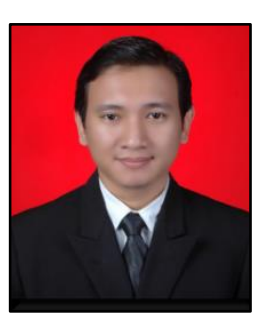

Lahir di Pati, 20 Juni 1987. Tahun 2009 memperoleh gelar S1 Pendidikan Matematika di Universitas Negeri Semarang dan kemudian melanjutkan S2 Pendidikan Matematika di Universitas Negeri Semarang pada tahun 2010 dan menyelesaikannya pada tahun 2012. Mengajar di Universitas Kristen Satya Wacana Salatiga sejak tahun 2012. 